\title{
A review of the literature on inclusive pedagogy in physical education 2005-2015
}

\begin{tabular}{c|c}
$\begin{array}{c}\text { Stephanie McNeil } \\
\text { Flinders University } \\
\text { stephanie.mcneil@flinders.edu.au }\end{array}$ & $\begin{array}{c}\text { Kerrie Lante } \\
\text { Flinders University } \\
\text { kerrie.lante@flinders.edu.au }\end{array}$ \\
Shane Pill \\
Flinders University \\
shane.pill@flinders.edu.au
\end{tabular}

Keywords: Inclusion, pedagogy, pre-service teachers, physical education

\begin{abstract}
Inclusive Education (IE) has been an important aspect of the Australian education system for several decades (Armstrong, Armstrong \& Barton, 2009). Students with disabilities (SWD) have a right to IE (Disability and Discrimination Act [DDA], 1992) and their development requires support, facilitation and the skill set from teachers to provide meaningful participation across all areas of the curriculum. However, there is limited information in Australia on how pre-service Physical Education (PE) teachers feel about their own ability to deliver inclusive pedagogy to SWD.
\end{abstract}

This paper uses a thematic approach derived from Wallhead and O'Sullivan (2005) to examine 22 peer-reviewed journal articles. The aim was to determine themes which can contribute to understanding the attitudes of pre-service PE teachers and their self-efficacy to design and enact inclusive pedagogy for SWD. Four themes and their implications emerged from the literature, these included; (a) measurements to examine attitudes of pre-service PE teachers, (b) exploring pre-service PE teacher's self-efficacy; (c) the effects of pre-service PE teachers' practicum experiences; and (d) investigating the hands-on opportunities in Physical Education Teacher Education (PETE) programs.

This review highlights inclusive pedagogy is inconsistently practiced at a pre-service level thereby affecting how pre-service PE teachers think when working with SWD. Subsequently, inconsistent practice requires PETE programs to review how inclusive pedagogy is incorporated into student learning outcomes for pre-service PE teachers to develop knowledge and practice for inclusion and, if it adequately prepares them to teach SWD.

Research (Hodge \& Elliot, 2013; Mangope, Mannathoko \& Kuyini, 2013; Pedersen, Cooley \& Hernandez, 2014) indicates inclusive pedagogy requires ongoing development at a pre-service level in order to increase the self-efficacy of pre-service teachers to provide meaningful opportunities for SWD in PE. From this review, the authors have identified there is a need to explore Australian pre-service PE teachers and their self-efficacy to design and enact inclusive pedagogy. Subsequently, further study needs to explore inclusive pedagogy in PE on a state-wide basis and how it can become embedded throughout an entire PETE program. 


\section{Introduction}

In the Australian educational context Physical Education (PE) is part of the learning area called Health and Physical Education (HPE), comprising the subject Health Education and Physical Education. In this paper, the term PE will be used to refer specifically to the subject called Physical Education, which in the Australian HPE Curriculum covers the student achievement standards of the Movement and Physical Activity strand (Australian Curriculum, Assessment and Reporting Authority [ACARA], 2015). Physical Education (PE) (rather than HPE) will also be preferred in the paper as $P E$ is the common term used in the literature informing this paper.

Physical Education (PE) for students with disabilities (SWD) is important for age-appropriate motor skill development, encouraging social skills and supporting health literacy to enable positive health outcomes (Bailey, 2005; Obrusníková, Válková \& Block, 2003; Ouellette-Kuntz, 2005). In a report by the Ministerial Advisory Committee to the South Australian Minister for Education and Child Development (Government of South Australia, 2010), it was reported people with a disability in South Australia were below the national average for physical activity levels among people with a disability. In particular, findings indicated SWD engaged in more sedentary and obesity related behaviours in their lifestyles (Government of South Australia, 2010). This has detrimental effects to the health and wellbeing of SWD and highlights the importance to focus on Inclusive Education (IE) in PE to promote and encourage physical activity.

Inclusive Education (IE) can be defined as education that is non-discriminatory and involves all students in a community (Ballard, 1997). Ballard (1997) also emphasises IE means 'students having equal rights to access the culturally valued curriculum of their society as full-timed valued members of age-appropriate mainstream classes... irrespective of their differences' ( $p$. 244). In Australia, IE is a human right which is underpinned by the Disability and Discrimination Act (DDA) (1992) and the United Nations Convention on the Rights of Persons with Disabilities (UNCRPD) (United Nations, 2006). Inclusive Education (IE) reflects the Social Model of Disability (Oliver, 1983) by implementing dynamic and adaptable environments where teachers can support all SWD and the diversity of their learning by creating equitable access and opportunities to participate in PE. As the prevalence of disability is increasing in the number of SWD attending mainstream schools (Australian Institute of Health and Welfare [AlHW], 2008) there is a greater need for teachers to be equipped to provide support, and be supported, to facilitate students' learning in their PE class (Government of South Australia, 2010).

The Disability Standards for Education (Australian Government, 2005) were created under the DDA to ensure SWD were given fair access to participate as fully as possible in all aspects of education. Although the Disability Standards provide a framework for participation, the Australian Curriculum provides support for all students to access the same content. A commitment to adopting inclusive pedagogy is highlighted in the HPE Australian Curriculum through the key ideas Take a strengths-based approach and Focus on educative purposes (ACARA, 2015). The key ideas recognise that students have various abilities and there is value in understanding their strengths when delivering inclusive pedagogy to enable SWD to achieve positive health behaviours in PE (AIHW, 2008; Government of South Australia, 2010). The DDA (1992), UNCRPD (United Nations, 2006) and the HPE Australian Curriculum (ACARA, 2015) are crucial in shaping opportunities for SWD, however this does not necessarily result in the application of inclusive pedagogy in practice. Inclusive pedagogy refers to promoting IE ensuring practice is based on the use of diverse teaching strategies (Corbett, 2001). Research highlights that pre-service PE teachers struggle with knowing how to teach SWD and the self-efficacy to enact inclusive pedagogy (Hodge \& Elliot, 2013; Mangope, Mannathoko \& Kuyini, 2013; Pedersen, Cooley \& Hernandez, 2014). From this research, the authors identify PE teachers' pedagogy to facilitate outcomes for a range of students is falling short upon the 
delivery of their teaching. The importance of acknowledging previous research (Hodge \& Elliot, 2013; Mangope et al., 2013; Pedersen et al., 2014) is to ensure the learning and development of pre-service teachers in Physical Education Teacher Education (PETE) programs reflects their ability to achieve the Professional Standards for Teaching (Australian Institute for Teaching and School Leadership [AITSL], 2011) in Australia. By ensuring quality learning and development, opportunities will ultimately be provided for pre-service PE teachers to engage in best practice for inclusive pedagogy. It is anticipated that this will in turn deliver meaningful opportunities to SWD in PE.

In this review, the authors identified that the impact of teachers' attitudes on the successful inclusion of SWD in PE is a dominant area of research in recent literature (Di Nardo, Kudláček, Tafuri \& Sklenaříková, 2014; Hodge \& Elliot, 2013; Mangope, Mannathoko \& Kuyini, 2013; Pedersen, Cooley \& Hernandez, 2014; Tindall, MacDonald, Carroll \& Moody, 2015). Intentions are influenced by a person's attitude toward their behaviour which Ajzen (1991) recognises through the Theory of Planned Behaviour (ToPB). By understanding the attitudes of pre-service $\mathrm{PE}$ teachers, together with their perceived subjective norms from society and control of their behaviour, intentions to teach SWD can be predicted (Ajzen, 1991).

In understanding the intention and behaviours of pre-service PE teachers towards teaching SWD, this review intends to explore the literature on inclusive pedagogy in PE using a thematic approach. The objective of this review is to highlight the key themes and their implications that emerge from the literature that will contribute to enabling better learning outcomes for preservice PE teachers and their inclusive pedagogy in South Australia.

\section{Method}

In searching for peer-reviewed journal articles on inclusive pedagogy in PE, the authors used open coding for initial identification of similarities. An inclusion criteria was also predetermined by the authors to allow a focus on pre-service PE teachers. The journal articles were to contain one or more of the following criteria; (1) instruments and measures used to obtain pre-service PE teachers' attitudes towards teaching SWD (2) results of pre-service PE teachers participating in Adapted Physical Education (APE) topics at university, and (3) reports on the self-efficacy of pre-service PE teachers towards teaching or working with SWD. The following codes were used to identify literature on pre-service PE teachers and their attitudes towards working with SWD; 'physical education teachers', 'attitudes towards disability', 'selfefficacy', 'disability', 'inclusive pedagogy', 'preservice teachers' and 'physical education'. These terms were chosen in order to identify literature according to the inclusion criteria set by the authors. The strategy involved finding articles in the English language between January 2005 and December 2015 to locate relevant literature across three databases ERIC (ProQuest), SCOPUS and Web of Science. Articles located through database searching together with journal articles obtained through citations within these articles were screened by reviewing the titles and abstracts against the inclusion criteria. For articles where abstracts were not available to view, the full-text was retrieved to determine if it reflected the inclusion criteria.

Despite previous literature reviews on inclusion in PE (Block \& Obrusnikova, 2007; Qi \& Ha, 2012) examining a broad overview of the construction and implementation of inclusive practice, to the best of our knowledge there are no reviews specific to inclusive pedagogy among pre-service PE teachers from 2005-2015. Therefore, studies which focused on perspectives from existing PE teachers and perspectives from students with and without disabilities were not included in this review. Additionally, professional development materials for existing PE teachers and books and doctoral dissertations on inclusive pedagogy in PE were also not included for the purpose of this review. 


\section{Results and discussion}

\section{Outline of the studies}

Twenty three peer-reviewed journal articles on inclusive pedagogy in PE were found. One article was not available to review due to unobtainable access to the full-text, therefore 22 articles were analysed in this review.

The majority of studies were conducted in the USA $(n=9)$ with remaining studies dispersed across other regions; Europe $(n=5)$, Asia $(n=5)$, Australia $(n=2)$ and Africa $(n=1)$. One study (Oh et al., 2010) was undertaken over three countries China, Korea and America and has been recorded under the Asian region.

Examination of the literature identified two main categories of studies. The first category includes studies designed to examine the attitudes of pre-service PE teachers towards working with students with disabilities (SWD). Although each of these studies measured the attitudes of pre-service PE teachers, the studies measured a number of different determinants of attitudes. These included;

- Evaluating the impact of coursework and teacher training in PE and/or Adapted Physical Education (APE) (Apache \& Rizzo, 2005; Coates, 2012; Di Nardo et al., 2014; Pedersen, Cooley \& Hernandez, 2014; Perlman \& Piletic, 2012; Schoffstall \& Ackerman, 2007).

- Evaluating the impact of pre-service PE teacher's practicum experiences (Lieberman \& Wilson, 2005; Rust \& Sinelnikov, 2010; Tindall, MacDonald, Carroll \& Moody, 2015).

- Personal variables (for example; previous experiences, age, gender) contributing to teaching SWD (Duchane et al., 2008; Hutzler et al., 2005; Oh et al., 2010).

- $\quad$ Current knowledge and perceptions about teaching SWD (Hodge \& Elliot, 2013; Mousouli, Kokaridas, Angelopoulou-Sakadami \& Aristotelous, 2009).

- Investigating attitudes to predict the intention to teach SWD (Martin \& Kudlacek, 2010), and

- Exploring attitudes towards teaching PE to students with various disability types (Mangope, Mannathoko \& Kuyini, 2013)

The second category includes studies designed to create and validate instruments used to measure attitudes of pre-service teachers (Block, Hutzler, Barak \& Klavina, 2013; Hodge, Sato, Mukoyama \& Kozub, 2013). Within both of these studies, attitudes were also measured following validation of the tool. A small number of studies $(n=3)$ were unique in their purpose and could not be classed in either of the two main categories. The purpose of these studies were to examine self-efficacy (Vickerman \& Coates, 2009), anxiety levels (Everhart, 2009), and identifying attitudes using visual information (Fethi, 2015). The authors adapted Wallhead and O'Sullivan's (2005) approach to review the 22 peer- reviewed journal articles. Results of the analysis are illustrated in table 1 and have been organised by study purpose, participants and setting, data collection methods, analysis, results and further recommendations. To help inform the authors of how to enable better learning outcomes for pre-service PE teachers and their inclusive pedagogy an additional category (further recommendations) was included. A review of this category helped the authors to identify areas of research requiring exploration. 
Table 1. Overview of reviewed journal articles for inclusive pedagogy in PE 2005-2015

\begin{tabular}{|c|c|}
\hline Study: & Apache \& Rizzo (2005) \\
\hline Study purpose & $\begin{array}{l}\text { Measure the attitudes of PE majors towards teaching SWD in regular } \\
\text { classrooms }\end{array}$ \\
\hline $\begin{array}{l}\text { Participants and } \\
\text { setting }\end{array}$ & $\begin{array}{l}91 \text { PE majors } \\
\text { One year disability infusion program } \\
\text { USA }\end{array}$ \\
\hline $\begin{array}{l}\text { Data collection } \\
\text { methods }\end{array}$ & $\begin{array}{l}\text { Pre and post test using The Physical Educator's Attitude Toward Teaching } \\
\text { Individuals with Disabilities III (PEATID III) scale (Rizzo, 1993) }\end{array}$ \\
\hline Analysis & $\begin{array}{l}\text { Means and standard deviations of pre and post test } \\
\text { Three dimensions of attitudes were assessed } \\
\text { 1. Perceptions of outcomes teaching SWD } \\
\text { 2. Perception of effects on student learning } \\
\text { 3. Perception of need for more academic preparation }\end{array}$ \\
\hline Results & $\begin{array}{l}\text { Dimension 1: No significant change } \\
\text { Dimension 2: Significant change: students with learning disabilities and } \\
\text { mild-moderate impairments between tests } \\
\text { Dimension 3: No significant change, however reported significant difference } \\
\text { in self-reported competence }\end{array}$ \\
\hline \multicolumn{2}{|l|}{$\begin{array}{l}\text { Further } \\
\text { recommendations }\end{array}$} \\
\hline Study: & Hutzler et al. (2005) \\
\hline Study purpose & $\begin{array}{l}\text { Investigate personal variables in PE students when teaching SWD in regular } \\
\text { classrooms }\end{array}$ \\
\hline $\begin{array}{l}\text { Participants and } \\
\text { setting }\end{array}$ & $\begin{array}{l}153 \text { from two major teacher colleges } \\
\text { Israel }\end{array}$ \\
\hline $\begin{array}{l}\text { Data collection } \\
\text { methods }\end{array}$ & $\begin{array}{l}\text { The Attitudes Towards Including students with a disability in PE lessons (ATIPE) } \\
\text { questionnaire (Shechtman, 1991). } \\
\text { The Self-Efficacy in teaching PE under inclusive conditions (SEIPE) self- } \\
\text { developed based on Bandura's (1997) constructions for self-efficacy } \\
\text { questionnaires }\end{array}$ \\
\hline Analysis & $\begin{array}{l}\text { Factor analysis with oblique VARIMAX rotations for ATIPE } \\
\text { One-way ANOVA with post hoc tests for SEIPE } \\
\text { Correlations established between attitudes and self-efficacy variables }\end{array}$ \\
\hline Results & $\begin{array}{l}\text { - The study confirms the hypothesis- self-efficacy related to attitudes towards } \\
\text { including SWD in PE. } \\
\text { - The instrument used suggests a three-fold factorial attitude concept } \\
\text { - Two threat scales; to the teacher and to the class } \\
\text { - One opportunities scale }\end{array}$ \\
\hline $\begin{array}{l}\text { Further } \\
\text { recommendations }\end{array}$ & $\begin{array}{l}\text { - Include simulations into introductory teacher courses } \\
\text { - Increase amount of guided training for inclusion type contexts } \\
\text { - } \quad \text { Foster teaching resources }\end{array}$ \\
\hline
\end{tabular}




\begin{tabular}{l|l}
\hline Study: & $\begin{array}{l}\text { Lieberman \& Wilson (2005) } \\
\text { Study purpose } \\
\text { Determine if attitudes of pre-service teachers would change after an intensive } \\
\text { practicum }\end{array}$ \\
$\begin{array}{l}\text { Participants and } \\
\text { setting }\end{array}$ & $\begin{array}{l}8 \text { PE majors, APE majors, fitness/wellness candidates } \\
8 \text { One week intensive sports camp practicum for children with visual impairments } \\
\text { USA } \\
\text { Pre and post survey containing statements measured against a Likert scale }\end{array}$ \\
$\begin{array}{l}\text { Data collection } \\
\text { methods }\end{array}$ & $\begin{array}{l}\text { Comparing responses pre and post practicum } \\
\text { Analysis }\end{array}$ \\
$\begin{array}{l}\text { Results } \\
\begin{array}{l}\text { Further } \\
\text { recommendations }\end{array}\end{array}$ & $\begin{array}{l}\text { Overall yes had positive changes to attitude } \\
\text { - Set up practicum experiences inclusive of children with visual impairments }\end{array}$ \\
\hline
\end{tabular}

\begin{tabular}{l|l}
$\begin{array}{l}\text { Study: } \\
\text { Study purpose }\end{array}$ & $\begin{array}{l}\text { Gursel (2007) } \\
\text { Compare the attitudes of PE majors and other sport majors regarding } \\
\text { individuals with physical disabilities }\end{array}$ \\
$\begin{array}{l}\text { Participants and } \\
\text { setting }\end{array}$ & $\begin{array}{l}\text { (PE majors- study group and other sport majors- control group) } \\
14 \text { week APE course } \\
2 \text { Universities } \\
\text { Turkey } \\
\text { The Attitude Towards Disability Persons (ATDP) scale, Form O (Yuker et al., }\end{array}$ \\
$\begin{array}{l}\text { Data collection } \\
\text { methods } \\
\text { Analysis }\end{array}$ & $\begin{array}{l}\text { ANCOVA used to examine differences } \\
\text { Results }\end{array}$ \\
$\begin{array}{l}\text { Positive changes in attitude found in PE major participants compared to } \\
\text { other sport majors after a combination of class work and personal contact }\end{array}$ \\
$\begin{array}{l}\text { Further } \\
\text { recommendation can be more positively influenced through APE courses }\end{array}$
\end{tabular}

\begin{tabular}{l|l}
\hline $\begin{array}{l}\text { Study: } \\
\text { Study purpose }\end{array}$ & $\begin{array}{l}\text { Schoffstall et al. (2007) } \\
\text { Examine the effects of an APE course on attitudes of future PE teachers } \\
\text { towards SWD }\end{array}$ \\
$\begin{array}{l}\text { Participants and } \\
\text { setting }\end{array}$ & $\begin{array}{l}\text { 108 APE students } \\
\text { Faith-based university } \\
\text { USA }\end{array}$ \\
$\begin{array}{l}\text { Data collection } \\
\text { methods }\end{array}$ & $\begin{array}{l}\text { The Physical Educator's Attitude Toward Teaching Individuals with Disabilities } \\
\text { III (PEATID III) Scale (Rizzo, 1993) } \\
\text { Short answer questions also delivered to available respondents } \\
\text { ANCOVA used to examine differences in pre and post test scores }\end{array}$ \\
$\begin{array}{l}\text { Analysis } \\
\text { Results }\end{array}$ & $\begin{array}{l}\text { Attitudinal scores significantly improved pre-test to post-test } \\
\text { When ToPB is applied, it made participants feel APE made them more } \\
\text { prepared and believed it positively influence their view of SWD. }\end{array}$ \\
$\begin{array}{l}\text { Further } \\
\text { recommendations }\end{array}$ &
\end{tabular}




\begin{tabular}{|c|c|}
\hline Study: & Duchane et al. (2008) \\
\hline Study purpose & $\begin{array}{l}\text { Examine the attitude of students in undergraduate PETE programs towards } \\
\text { teaching SWD }\end{array}$ \\
\hline $\begin{array}{l}\text { Participants and } \\
\text { setting }\end{array}$ & $\begin{array}{l}183 \text { PE majors } \\
\text { Two colleges } \\
\text { USA }\end{array}$ \\
\hline $\begin{array}{l}\text { Data collection } \\
\text { methods }\end{array}$ & $\begin{array}{l}\text { The Attitude Towards Disability Persons (ATDP) scale (Yuker et al., 1970). } \\
\text { Revised }\end{array}$ \\
\hline Analysis & One-shot survey design with a series of t-tests \\
\hline Results & $\begin{array}{l}\text { - A pre-service teachers gender, previous experience with individuals with } \\
\text { disabilities and academic preparation are factors that relate to attitude }\end{array}$ \\
\hline $\begin{array}{l}\text { Further } \\
\text { recommendations }\end{array}$ & $\begin{array}{l}\text { - Reassess curriculum and determine what information is important } \\
\text { - Key questions when evaluating: 'Are the courses provided relevant to } \\
\text { inclusive classrooms that exist?' and 'What do our students need in order } \\
\text { to feel competent?' (p. 19) }\end{array}$ \\
\hline
\end{tabular}

\begin{tabular}{|c|c|}
\hline Study: & Everhart (2009) \\
\hline Study purpose & $\begin{array}{l}\text { Preliminary look at PE majors and their anxiety when teaching students with } \\
\text { and without disabilities }\end{array}$ \\
\hline $\begin{array}{l}\text { Participants and } \\
\text { setting }\end{array}$ & $\begin{array}{l}6 \text { senior PE majors } \\
\text { Enrolled in APE course } \\
\text { One university } \\
\text { USA }\end{array}$ \\
\hline $\begin{array}{l}\text { Data collection } \\
\text { methods }\end{array}$ & $\begin{array}{l}\text { Pre-teaching interviews, questionnaires, heart rate analysis (worn when } \\
\text { teaching students with and without disabilities) }\end{array}$ \\
\hline Analysis & Heart rate graphical trends to assess anxiety levels \\
\hline Results & $\begin{array}{l}\text { Dominant perspective= apprehensive however looked forward to teaching } \\
\text { SWD } \\
\text { - Anxiety related to unfamiliarly }\end{array}$ \\
\hline $\begin{array}{l}\text { Further } \\
\text { recommendations }\end{array}$ & $\begin{array}{l}\text { Other curriculum models and instructional strategies should be investigated } \\
\text { to determine ways to alleviate anxiety and prepare pre-service PE teachers } \\
\text { better }\end{array}$ \\
\hline
\end{tabular}

\begin{tabular}{|c|c|}
\hline Study: & Mousouli et al. (2009) \\
\hline Study purpose & Explore knowledge and attitudes of PE students towards SWD \\
\hline $\begin{array}{l}\text { Participants and } \\
\text { setting }\end{array}$ & $\begin{array}{l}140 \text { first-fourth year PE students } \\
\text { One university } \\
\text { Greece }\end{array}$ \\
\hline $\begin{array}{l}\text { Data collection } \\
\text { methods }\end{array}$ & Questionnaire \\
\hline Analysis & SPSS 10 for descriptive analysis results \\
\hline Results & - The acceptance of SWD in regular schools considered moderate \\
\hline $\begin{array}{l}\text { Further } \\
\text { recommendations }\end{array}$ & $\begin{array}{l}\text { - A wider range of information about people with disability and their needs } \\
\text { can lead to an increased acceptance of children SWD in regular schools }\end{array}$ \\
\hline
\end{tabular}




\begin{tabular}{|c|c|}
\hline Study: & Vickerman \& Coates (2009) \\
\hline Study purpose & $\begin{array}{l}\text { Examine the perspectives of trainee teachers in relation to their perceived } \\
\text { readiness to include SWD }\end{array}$ \\
\hline $\begin{array}{l}\text { Participants and } \\
\text { setting }\end{array}$ & $\begin{array}{l}202 \text { final year trainee } P E \text { teachers } \\
5 \text { PE training providers } \\
\text { England }\end{array}$ \\
\hline $\begin{array}{l}\text { Data collection } \\
\text { methods }\end{array}$ & Questionnaire \\
\hline Analysis & $\begin{array}{l}\text { Stage one and two questionnaires- SPSS } 14 \text {. } \\
\text { Open-ended responses using protocol analysis }\end{array}$ \\
\hline Results & $\begin{array}{l}\text { - } 43 \% \text { of trainee teacher respondents indicated they weren't adequately } \\
\text { prepared }\end{array}$ \\
\hline $\begin{array}{l}\text { Further } \\
\text { recommendations }\end{array}$ & $\begin{array}{l}\text { - Further research needs to link 'teaching, learning and differentiation' (p. 151) } \\
\text { directly to SWD } \\
\text { - Training should be inclusive for the duration of a course } \\
\text { - More practical training than theoretical preferable as it provides preparation } \\
\text { for teaching a SWD }\end{array}$ \\
\hline
\end{tabular}

\begin{tabular}{l|l}
\hline $\begin{array}{l}\text { Study: } \\
\text { Study purpose }\end{array}$ & $\begin{array}{l}\text { Oh et al. (2010) } \\
\text { Examine pre-service teacher-related variables associated with ToPB towards } \\
\text { students labelled ADHD in regular classes } \\
213 \text { pre-service teachers across } \\
\text { Universities in China, Korea, USA }\end{array}$ \\
$\begin{array}{l}\text { Participants and } \\
\text { setting } \\
\text { methods collection }\end{array}$ & $\begin{array}{l}\text { Physical Educators' Intention toward Teaching Individuals with Disabilities II } \\
\text { Preservice Survey (PEITID-II-PS). (Ajzen, 2002) }\end{array}$ \\
Analysis & $\begin{array}{l}\text { Descriptive statistics for means and standard deviation of items and ToPB } \\
\text { measures } \\
\text { One-way ANOVA to examine gender differences } \\
\text { Previous experience and perceived competence had significant positive } \\
\text { influence on intentions and perceived behavioural control } \\
\text { Behavioural beliefs are predicted by prior teaching experience, age, and } \\
\text { special education coursework }\end{array}$ \\
Results & $\begin{array}{l}\text { Teacher-related variables influence attitudinal beliefs of pre-service PE } \\
\text { teachers } \\
\text { The findings provide additional evidence for a need to change the culture } \\
\text { of PETE programs at college and universities }\end{array}$ \\
$\begin{array}{l}\text { Further } \\
\text { recommendations }\end{array}$
\end{tabular}




\begin{tabular}{|c|c|}
\hline Study: & Rust \& Sinelnikov (2010) \\
\hline Study purpose & $\begin{array}{l}\text { Explore pre-service PE teacher perceptions of teaching SWD and professional } \\
\text { preparation }\end{array}$ \\
\hline $\begin{array}{l}\text { Participants and } \\
\text { setting }\end{array}$ & $\begin{array}{l}1 \text { pre-service teacher } \\
\text { Self-contained environment during a } 7 \text { week student teaching practicum } \\
\text { USA }\end{array}$ \\
\hline $\begin{array}{l}\text { Data collection } \\
\text { methods }\end{array}$ & Case study: Formal and informal interviews, direct observation, reports \\
\hline Analysis & Thematic analysis to identify common themes \\
\hline Results & $\begin{array}{l}\text { Participant acknowledges understanding of disabilities however the } \\
\text { knowledge of how to teach SWD crucial } \\
\text { Participant had low expectations to begin but was alleviated by the end of } \\
\text { the practicum } \\
\text { - Participant highlighted importance of language and finding other ways to } \\
\text { describe techniques/give cues/feedback }\end{array}$ \\
\hline $\begin{array}{l}\text { Further } \\
\text { recommendations }\end{array}$ & - PETE programs need to make any field experiences as genuine as possible \\
\hline
\end{tabular}

\begin{tabular}{|c|c|}
\hline Study: & Martin \& Kudlacek (2010) \\
\hline Study purpose & $\begin{array}{l}\text { Investigate and describe the attitudes of pre-service PE teachers attempting to } \\
\text { predict their intentions to include students with physical disabilities }\end{array}$ \\
\hline $\begin{array}{l}\text { Participants and } \\
\text { setting }\end{array}$ & $\begin{array}{l}230 \\
\text { First and fourth year } \\
\text { Primary and PE courses } \\
\text { Australia }\end{array}$ \\
\hline $\begin{array}{l}\text { Data collection } \\
\text { methods }\end{array}$ & $\begin{array}{l}\text { The Attitudes Towards Individuals with Physical Disabilities in Physical } \\
\text { Education (ATIPDPE) instrument } \\
\text { (Kudláček et al., 2002). Revised }\end{array}$ \\
\hline Analysis & $\begin{array}{l}\text { One-way ANOVA } \\
\text { SPSS } 13\end{array}$ \\
\hline Results & $\begin{array}{l}\text { - Overall, participants held positive attitudes towards including students with } \\
\text { physical disabilities } \\
\text { - Year level produces no significant difference }\end{array}$ \\
\hline $\begin{array}{l}\text { Further } \\
\text { recommendations }\end{array}$ & $\begin{array}{l}\text { - Incorporate education relating to inclusion in more core topics throughout } \\
\text { a course } \\
\text { - Ongoing research needs to occur to provide valuable feedback to teaching } \\
\text { institutions } \\
\text { - Explore differences among students who have/ have not completed topics } \\
\text { related to teaching SWD } \\
\text { - Pre and post study at the beginning and end of students university careers } \\
\text { - Necessary to complete similar research throughout a number of locations } \\
\text { throughout Australia }\end{array}$ \\
\hline
\end{tabular}




\begin{tabular}{l|l}
\hline $\begin{array}{l}\text { Study: } \\
\text { Study purpose }\end{array}$ & $\begin{array}{l}\text { Coates (2012) } \\
\text { Examine the training student PE teachers receive in relation to teaching in } \\
\text { inclusive environments and how well it prepares them to teach confidently }\end{array}$ \\
$\begin{array}{l}\text { Participants and } \\
\text { setting }\end{array}$ & $\begin{array}{l}112 \text { trainee secondary PE teachers } \\
\text { One university } \\
\text { England }\end{array}$ \\
$\begin{array}{l}\text { Data collection } \\
\text { methods }\end{array}$ & $\begin{array}{l}\text { Case study: Semi-structured questionnaire } \\
\text { Analysis }\end{array}$ \\
$\begin{array}{l}\text { SPSS } 17 \text { (closed questions) } \\
\text { Thematic analysis using NVivo (open questions) } \\
\text { Results }\end{array}$ & $\begin{array}{l}\text { The inclusion training received was felt to be ineffective } \\
\text { A more hands-on approach and activity specific training necessary }\end{array}$ \\
$\begin{array}{l}\text { Anther inclusion philosophy should be embedded to all areas of teaching } \\
\text { training curriculum } \\
\text { recommendations having this approach it may develop confident PE teachers inclusive } \\
\text { of SWD }\end{array}$ \\
\hline
\end{tabular}

\begin{tabular}{|c|c|}
\hline Study: & Perlman \& Piletic (2012) \\
\hline Study purpose & $\begin{array}{l}\text { Investigate the influence of an APE course on PETE students and their ability } \\
\text { to design and implement instruction }\end{array}$ \\
\hline $\begin{array}{l}\text { Participants and } \\
\text { setting }\end{array}$ & $\begin{array}{l}46 \text { Pre-service PE teachers enrolled in of two PETE programs } \\
\text { USA }\end{array}$ \\
\hline $\begin{array}{l}\text { Data collection } \\
\text { methods }\end{array}$ & $\begin{array}{l}\text { Qualitative case study approach: Scenario responses, teacher reflections and } \\
\text { peer observations }\end{array}$ \\
\hline Analysis & $\begin{array}{l}\text { Verbatim transcription across all three measures utilising the constant- } \\
\text { comparative method }\end{array}$ \\
\hline Results & $\begin{array}{l}\text { - PETE students indicated the use of feedback, task variation and teaching } \\
\text { to the students' needs were key in providing motivational instruction }\end{array}$ \\
\hline $\begin{array}{l}\text { Further } \\
\text { recommendations }\end{array}$ & $\begin{array}{l}\text { - There is a need for a combination of theory based and practical application } \\
\text { courses infusing authentic field based experiences } \\
\text { - For quality experiences, PETE students may benefit from common theme } \\
\text { that can be reinforces throughout the entire teacher development program }\end{array}$ \\
\hline
\end{tabular}




\begin{tabular}{l|l}
\hline Study: & Block et al. (2013) \\
$\begin{array}{l}\text { Study purpose } \\
\text { Participants and } \\
\text { setting }\end{array}$ & $\begin{array}{l}\text { Create and analyse properties of a survey instrument the SE-PETE-D } \\
\text { 486 PETE majors } \\
\text { USA }\end{array}$ \\
$\begin{array}{l}\text { Data collection } \\
\text { methods }\end{array}$ & $\begin{array}{l}\text { Self-Efficacy of Physical Education Teacher Education majors towards children } \\
\text { with Disabilities (SE-PETE-D) (Block et al., 2013) comprised of three disability- } \\
\text { specific scales (Intellectual disability, physical disability and visual impairment) }\end{array}$ \\
$\begin{array}{l}\text { Enalysis } \\
\text { Exploratory factor analysis and } \\
\text { Confirmatory factor analysis }\end{array}$ \\
$\begin{array}{l}\text { A variety of factors across all three scales provided empirical evidence for what } \\
\text { PETE students perceive as expertise domains to be inclusive of SWD in regular } \\
\text { classes: }\end{array}$ \\
$\begin{array}{l}- \text { Instructing peers to assist SWD } \\
- \text { Coping with specific adaption requirements } \\
- \text { Assuring the safety of SWD } \\
- \text { Adapting instruction to keep SWD on task } \\
\text { A need for qualitative studies to understand the reasons behind } \\
\text { self-efficacy of PETE students, specific to their majors }\end{array}$ \\
$\begin{array}{l}\text { Further } \\
\text { recommendations }\end{array}$
\end{tabular}

\begin{tabular}{|c|c|}
\hline Study: & Hodge \& Elliot (2013) \\
\hline Study purpose & Analyse the beliefs about inclusion and teaching SWD \\
\hline $\begin{array}{l}\text { Participants and } \\
\text { setting }\end{array}$ & $\begin{array}{l}177 \text { PE majors and other sport majors } \\
\text { Minority-serving institutes } \\
\text { USA }\end{array}$ \\
\hline $\begin{array}{l}\text { Data collection } \\
\text { methods }\end{array}$ & $\begin{array}{l}\text { Physical Educators' Judgments about Inclusion (PEJI) survey (Hodge et al., } \\
\text { 2002) }\end{array}$ \\
\hline Analysis & ANOVA test \\
\hline Results & $\begin{array}{l}\text { - Most participants believed they needed more and better training to acquire } \\
\text { knowledge and skills before feeling confident to teach SWD }\end{array}$ \\
\hline $\begin{array}{l}\text { Further } \\
\text { recommendations }\end{array}$ & $\begin{array}{l}\text { - There is a need for better preparation for PE majors } \\
\text { - APE content coupled with practicum experiences is requisite to teachers } \\
\text { becoming more accepting of teaching SWD }\end{array}$ \\
\hline
\end{tabular}




\begin{tabular}{l|l}
\hline $\begin{array}{l}\text { Study: } \\
\text { Study purpose }\end{array}$ & $\begin{array}{l}\text { Hodge et al. (2013) } \\
\text { Assess the validity and reliability of PEJI and Analyse PETE majors judgements } \\
\text { as a function of their gender and past experiences }\end{array}$ \\
$\begin{array}{l}\text { Participants and } \\
\text { setting }\end{array}$ & $\begin{array}{l}531 \text { undergraduate PETE students } \\
\text { One university } \\
\text { Japan }\end{array}$ \\
$\begin{array}{l}\text { Data collection } \\
\text { methods }\end{array}$ & $\begin{array}{l}\text { Physical Educators' Judgments about Inclusion (PEJI) survey (Hodge et al., } \\
\text { 2002) }\end{array}$ \\
$\begin{array}{l}\text { Analysis } \\
\text { Results }\end{array}$ & $\begin{array}{l}\text { A series of one-way ANOVA tests } \\
\text { Most students yet to teach SWD but had developed positive or negative } \\
\text { preliminary judgements about teaching SWD } \\
\text { A need to examine the longstanding assumption that beliefs (judgements) } \\
\text { influence PE teachers actual teaching behaviour } \\
\text { Needs to be collected from future and current PE teachers in teaching SWD }\end{array}$ \\
\hline $\begin{array}{l}\text { Further } \\
\text { recommendations }\end{array}$
\end{tabular}

\begin{tabular}{l|l}
$\begin{array}{l}\text { Study: } \\
\text { Study purpose }\end{array}$ & $\begin{array}{l}\text { Mangope et al. (2013) } \\
\text { Identify the attitudes of PE teachers toward the inclusion of students with } \\
\text { varying types of disability into their general education classrooms }\end{array}$ \\
$\begin{array}{l}\text { Participants and } \\
\text { setting }\end{array}$ & $\begin{array}{l}\text { 96 PE student teachers } \\
\text { One university } \\
\text { Botswana }\end{array}$ \\
$\begin{array}{l}\text { Data collection } \\
\text { methods }\end{array}$ & $\begin{array}{l}\text { Attitude toward the inclusion of individuals with disabilities (ATIES) scale } \\
\text { (Wilczenski, 1995) }\end{array}$ \\
$\begin{array}{l}\text { Analysis } \\
\text { Results }\end{array}$ & $\begin{array}{l}\text { Factor analysis } \\
\text { - Overall the teachers held moderately positive attitudes towards IE } \\
\text { - Concerns included; teacher skills, time pressures, resources and the } \\
\text { negative impact on students without disabilities }\end{array}$ \\
$\begin{array}{l}\text { Further } \\
\text { recommendations }\end{array}$ & $\begin{array}{l}\text { Student teachers have the content to learn to teach however, knowing how } \\
\text { to teach SWD is valuable to making learning more meaningful and enjoyable }\end{array}$ \\
\hline
\end{tabular}

\begin{tabular}{l|l}
\hline $\begin{array}{l}\text { Study: } \\
\text { Study purpose }\end{array}$ & $\begin{array}{l}\text { Di Nardo et al. (2014) } \\
\text { Examine the effects of an APE course on the attitudes of pre-service PE } \\
\text { teachers towards students with a physical disability }\end{array}$ \\
$\begin{array}{l}\text { Participants and } \\
\text { setting }\end{array}$ & $\begin{array}{l}125 \text { PE students in first and third year PETE courses } \\
\text { One university } \\
\text { Italy } \\
\text { The Attitudes Towards Individuals with Physical Disabilities in Physical } \\
\text { Education (ATIPDPE) instrument } \\
\text { methods }\end{array}$ \\
$\begin{array}{l}\text { (Kudláček et al., 2002). } \\
\text { Analysis }\end{array}$ & $\begin{array}{l}\text { SPSS 17 } \\
\text { Results }\end{array}$ \\
$\begin{array}{l}\text { Further } \\
\text { recommendignificant differences between overall attitudes in all year levels } \\
\text { The intention toward inclusion increased with more education }\end{array}$ \\
\hline
\end{tabular}




\begin{tabular}{|c|c|}
\hline Study: & Pedersen et al. (2014) \\
\hline Study purpose & $\begin{array}{l}\text { Examine the effect of teaching training on pre-service PE teachers' intention to } \\
\text { include SWD in general PE classes }\end{array}$ \\
\hline $\begin{array}{l}\text { Participants and } \\
\text { setting }\end{array}$ & $\begin{array}{l}56 \\
\text { Third or fourth year students } \\
\text { Two universities } \\
\text { Australia }\end{array}$ \\
\hline $\begin{array}{l}\text { Data collection } \\
\text { methods }\end{array}$ & $\begin{array}{l}\text { Physical Educators' Intention toward Teaching Individuals with Disabilities } \\
\text { (PEITID) survey (Rizzo, 1993) }\end{array}$ \\
\hline Analysis & SPSS \\
\hline Results & $\begin{array}{l}\text { Both university groups in general had favourable attitudes towards teaching } \\
\text { SWD } \\
\text { The University group who received more training had more favourable } \\
\text { beliefs, attitudes and intentions } \\
\text { - The main point of difference was the practicum with SWD, therefore to } \\
\text { improve intention towards teaching SWD, more practicum experience is } \\
\text { reflective of what students will experience in their teaching careers and is } \\
\text { needed }\end{array}$ \\
\hline $\begin{array}{l}\text { Further } \\
\text { recommendations }\end{array}$ & $\begin{array}{l}\text { - A need to identify which aspect of pre-service teacher training provides the } \\
\text { biggest effect } \\
\text { - Compared to USA, there are no mandated units of work associated with } \\
\text { APE for Australian PETE programs in any registration board guidelines } \\
\text { - A need for more comprehensive research in Australia }\end{array}$ \\
\hline
\end{tabular}

\begin{tabular}{l|l}
\hline $\begin{array}{l}\text { Study: } \\
\text { Study purpose }\end{array}$ & $\begin{array}{l}\text { Fethi (2015) } \\
\text { Identify the attitudes of PE teacher candidates towards SWD using visual } \\
\text { information }\end{array}$ \\
$\begin{array}{l}\text { Participants and } \\
\text { setting }\end{array}$ & $\begin{array}{l}33 \\
\text { One university } \\
\text { Turkey }\end{array}$ \\
$\begin{array}{l}\text { Data collection } \\
\text { methods }\end{array}$ & $\begin{array}{l}\text { The Attitude Towards Disability Persons (ATDP) scale, Form O (Yuker et al., } \\
1970) \\
\text { Analysis }\end{array}$ \\
$\begin{array}{l}\text { Before and after the display of a short movie, evaluated using paired sample } \\
\text { t-test } \\
\text { Results }\end{array}$ & $\begin{array}{l}\text { A change in attitudes did not happen before or after the visual briefing, } \\
\text { however PE teacher candidates did not have a negative attitude either }\end{array}$ \\
$\begin{array}{l}\text { Further } \\
\text { recommendations }\end{array}$ &
\end{tabular}




\begin{tabular}{l|l}
$\begin{array}{l}\text { Study: } \\
\text { Study purpose }\end{array}$ & $\begin{array}{l}\text { Tindall et al. (2015) } \\
\text { Examine how the attitudes and perceptions of pre-service PE teachers change } \\
\text { as result of a semester long practicum with SWD }\end{array}$ \\
$\begin{array}{l}\text { Participants and } \\
\text { setting }\end{array}$ & $\begin{array}{l}64 \\
\text { Third year PE students } \\
10 \text { week APA program } \\
\text { Ireland }\end{array}$ \\
$\begin{array}{l}\text { Data collection } \\
\text { methods }\end{array}$ & $\begin{array}{l}\text { Written pieces: Pre-program expectations, weekly reflective blogs and a final } \\
\text { written reflection }\end{array}$ \\
$\begin{array}{l}\text { Analysis } \\
\text { Results }\end{array}$ & $\begin{array}{l}\text { Selective coding using NVivo } \\
\text { Attitude and perceptions improved through participating in the training } \\
\text { experience; lectures and an immediate and prolonged practicum experience } \\
\text { Further examination on themes of comfort, confidence, expectations, } \\
\text { understanding and observation as a means to inform other PETE programs }\end{array}$ \\
\hline $\begin{array}{l}\text { Further } \\
\text { recommendations }\end{array}$
\end{tabular}

The authors identified four themes from the literature. Findings related to each theme are discussed below.

\section{Measurements to examine attitudes of pre-service PE teachers}

Research on teacher's attitudes in PE is recognised by Mangope et al. (2013) as an important consideration for the successful inclusion of students with disabilities (SWD). Fethi (2015) identifies attitudes are not innate but achieved through education and therefore can change. Furthermore, Ajzen (1991) recognises by understanding attitudes, intentions to perform a behaviour can be predicted and can result in additional changes. As illustrated in table 1, fifteen $(68 \%)$ of the studies used a validated instrument to measure the attitudes of their participants. Among these fifteen studies there were eight validated instruments recorded to measure the attitudes of pre-service PE teachers. The tools used had the purpose of; evaluating attitudes based upon working with specific disability types (ATIPDPE) (Kudláček, Válková, Sherrill, Myers \& French, 2002) and differences in thinking affecting behaviour including; attitudes (PEATID III) (Rizzo, 1993), (ATIPE) (Shechtman, 1991), (ATDP) (Yuker, Block \& Young, 1970), (ATIES) (Wilczenski, 1995), intentions (PEITID-II-PS) (Ajzen, 2002), self-efficacy (SE-PETE-D) (Block et al., 2013) and judgements (PEJI) (Hodge, Murata \& Kozub, 2002).

Six of the journal articles reviewed used Theory of Planned Behaviour (ToPB) to evaluate attitudes of pre-service PE teachers. Theory of Planned Behaviour (ToPB) puts forward a notion derived from the Theory of Reasoned Action (Fishbein, 1967) recognising that the best prediction of behaviour is identifying the intention which can result in attitudinal changes (Ajzen, 1991). When applied to pre-service PE teachers it examines the relationship between their attitudes towards working with SWD and how it affects their teaching. The studies using ToPB utilised belief statements or vignettes to evaluate the attitudes of participants using a Likert scale. An example of how researchers have constructed their instruments utilising the ToPB's determinants of intentions can be seen in Di Nardo et al.'s (2014) study. Di Nardo et al. (2014) utilised the Attitudes Towards Individuals with Physical Disabilities in Physical Education (ATIPDPE) instrument in ToPB to link the beliefs of pre-service PE teachers towards students with a physical disability and their behaviours to teach. All six studies utilising ToPB used the same determinants. An example of the ToPB determinants in Di Nardo et al.'s (2014) study include; 
a. Examining pre-service PE teachers' attitudes towards teaching SWD (the behaviour). The researchers presented positive belief statements when including students with physical disabilities in their class and the benefits of this to examine their attitudes towards teaching.

b. Subjective norms. The impact of social pressure also predicts behaviours. This was presented through statements such as 'most people...think I should...' (p. 217) to examine normative beliefs of participants; and

c. Perceived behavioural control. Perception can also be measured to gain insight into pre-service PE teachers ease or difficulty to teach and was presented in this study through statements such as 'if I wanted to I would be able to...' (p. 217).

By studies utilising ToPB it enables use of a validated approach to examine the relationship between attitudes of pre-service PE teachers and their behaviour to teach SWD. The use of a validated approach enables an accurate process of measurement to gain an outcome. When using the ToPB model, it was identified in the work of Schoffstall et al. (2007), that when ToPB was applied to examine participants' attitudes it indicated students who participated in an Adapted Physical Education (APE) program reported having positive views of SWD. Therefore, this positively influenced their behaviours to teach. The authors of this review identify it is important to recognise the beliefs of pre-service PE teachers as their intentions correlate to the meaningful opportunities presented to SWD in PE.

Additional forms of measurement to examine attitudes of pre-service PE teachers are seen in table 1. Examples of these include; a questionnaire (Coates, 2012; Mousouli et al., 2009; Vickerman \& Coates, 2009) or a pre and post survey (Liberman \& Wilson, 2005). Further studies use a combination of approaches to achieve their outcome. Rust and Sinelnikov (2010) used informal and formal interviews with practical observation notes and critical incident reports. Similarly, Everhart (2009) also conducted interviews prior to teaching however this was in conjunction with measuring the heart rate of participants when teaching students with and without disabilities. Reflection was another measure used by Pearlman and Piletic (2012). Reflection was used in combination with scenario responses and peer observations to capture attitudinal changes. Tindall et al. (2015) also incorporated reflection into their study as a final practicum measure. However, this was in combination with written accounts of pre-practicum expectations and weekly blogs.

No matter the instrument used to measure pre-service PE teachers' attitudes towards teaching SWD, it was found that pre-service PE teachers held positive intentions about SWD and reported changes in attitude and competence towards teaching SWD in PE (Apache \& Rizzo, 2005; Di Nardo et al.,2014; Gursel, 2007; Liberman \& Wilson, 2005; Mangope et al., 2013; Martin \& Kudlacek, 2010; Oh et al., 2010; Pedersen et al., 2014; Schoffstall et al., 2007; Tindall et al., 2015). The factors influencing these findings range from; previous experience with people living with disability and perceived competence (Oh et al., 2010), education presented through coursework (Apache \& Rizzo, 2005; Di Nardo et al., 2014; Gursel, 2007; Martin \& Kudlacek, 2010; Mangope et al., 2013; Pedersen et al., 2014; Schoffstall et al., 2007) and contact with people living with disability in a PE practicum (Liberman \& Wilson, 2005; Tindall et al., 2015). On examination of table 1 it is seen that despite the positive intentions of pre-service $\mathrm{PE}$ teachers they have limited self-efficacy to translate knowledge and experiences into designing and enacting inclusive pedagogy for SWD. Within the reviewed studies, it was highlighted that attitudes of pre-service teachers were measured to evaluate the impact of coursework pre, during and/or post delivery in inclusive pedagogy (Apache \& Rizzo, 2005; Coates, 2012; Di Nardo et al., 2014; Gursel, 2007; Pedersen et al., 2014; Perlman \& Piletic 2012; Schoffstall et al., 2007). Through analysing table 1 it became evident there was inadequate training at a preservice level which meant teachers did not feel confident in their pedagogy when working with students with disabilities (SWD). 
Pre-service PE teachers indicated they needed added and improved content on inclusion in PE to acquire appropriate knowledge and skills in order to teach SWD (Hodge \& Elliot, 2013; Mangope et al., 2013; Pedersen et al., 2014). This is illustrated in the study by Mangope et al. (2013) which reported that pre-service PE teachers who held moderately positive attitudes still had concerns in their teaching skills and the available resources to support their teaching of SWD. Similarly, Hodge and Elliot (2013) report that participants needed more skills to learn how to teach SWD before feeling confident to teach. The significance of training is further highlighted by Pedersen et al. (2014) who found from comparing two university cohorts, the group who received more training had more favourable beliefs towards SWD. There is still a need to identify which aspect of pre-service training provides the greatest effect. This will in turn enable more effective training experiences and development of knowledge for pre-service students (Pedersen et al., 2014).

After reviewing the literature, the authors acknowledge that it is challenging for PE teachers to accommodate and modify their pedagogy for SWD. Hodge and Elliot (2013) conclude that how PE teachers enact their pedagogy is a reason why SWD may not experience success in $P E$. Therefore, there is a need to develop inclusive pedagogy in coursework for pre-service PE teachers. The authors believe this may alleviate many of the fears pre-service PE teachers may have towards working with SWD. This may in turn assist pre-service PE teachers to more fully consider how they could be more inclusive of SWD in PE.

\section{Exploring the self-efficacy of pre-service PE teachers}

As noted by Hodge and Elliot (2013), pre-service PE teachers have fear and apprehension about their skills and knowledge to teach SWD. Researchers have attempted to explore pre-service PE teachers' self-efficacy to examine how this impacts the development of their inclusive pedagogy to teach SWD. Self-efficacy has been explored by Block et al. (2013) who surveyed approximately 500 PETE students. Using results from the validated survey SelfEfficacy of Physical Education Teacher Education majors towards children with Disabilities (SE-PETE-D), Block et al. (2013) argued that to understand the factors which contribute to the self-efficacy of pre-service PE teachers, self-efficacy should be further investigated within different cohorts enrolled in PETE programs. For example, pre-service PE teachers undertaking streams such as Adapted Physical Education (APE) or students' involved in any PE practicum experience. This is supported by Pedersen et al. (2014) who compared two university cohorts using the Physical Educators' Intention toward Teaching Individuals with Disabilities (PEITID) survey (Rizzo, 1993). They found the group which had more exposure to practicums had more favourable beliefs to teaching SWD.

Despite differences in approaches between Pedersen et al.'s (2014) and Block et al.'s (2013) studies both concluded that there is no definitive results on pre-service PE teacher's selfefficacy. However, what Block et al. (2013) and Pedersen et al. (2014) suggest is the need to explore if practicum experiences helps PETE majors (students) develop skills and self-efficacy towards teaching SWD in a general PE class. This exploration can positively influence preservice PE teacher's intentions and development of pedagogy to teach SWD which will have an encouraging effect on the delivery of the PE Australian curriculum (ACARA, 2015) to SWD.

\section{The effects of pre-service PE teachers' practicum experiences}

Within the reviewed studies, it was identified a number of journal articles examined the impact of practicum experiences on pre-service PE teachers attitudes towards working with students with disabilities (SWD). Block et al. (2013) describes there is a need to evaluate practicum experiences to understand the factors contributing to self-efficacy of pre-service PE teachers. Rust and Sinelnikov's (2010) case study, involving one participant, explored the perceptions of 
pre-service PE teachers after they had taught SWD during a seven week teaching practicum. Findings from formal and informal interviews, direct observation and reports from the participant highlighted they had an understanding of disabilities, however upon reflection the participant emphasised that having knowledge around how to teach SWD is crucial for successful inclusion (Rust and Sinelnikov's, 2010). Similarly, Liberman and Wilson's (2005) study aimed to determine if attitudes of pre-service PE teachers would change after an intensive one week practicum specifically working with children with visual impairments. Likert scale responses were compared pre and post the practicum. It was found that pre-service PE teachers had positive changes in their attitude (Liberman \& Wilson, 2005). Likewise, Tindall et al. (2015) conducted a semester-long examination of written pieces (pre-program expectations, weekly blogs, final reflection) by third year PE students to examine how their attitudes changed as a result of a practicum with SWD. It found through students exposure to lectures encompassing inclusive pedagogy and experiences with SWD their attitudes improved towards teaching SWD (Tindall et al., 2015).

From these studies, it was found pre-service PE teachers had positive changes in their attitudes due to exposure to coursework on inclusive pedagogy combined with the opportunity to enact this with SWD through practicum experiences. More practicum experiences are reflective of what pre-service PE teachers will experience in their careers and is therefore needed (Pedersen et al., 2014). However, the authors believe the studies evaluating the impact of the practicum experience on attitudes of pre-service PE teachers has highlighted a gap in the literature. The practicum experiences identified involve teaching SWD however it is not implemented in an environment with students with and without disabilities, corresponding with Inclusive Education (IE). Most importantly, this can link to the low self-efficacy of pre-service PE teachers to translate knowledge and experiences gained from practicum experiences into designing and enacting inclusive pedagogy for SWD in general PE .

\section{Investigating hands-on opportunities in Physical Education Teacher Education (PETE) programs}

Within Australia, there are no mandated units of work associated with Adapted Physical Education (APE) for PETE programs in any registration board guidelines (Pedersen et al., 2014). A number of studies highlight the importance of a hands-on approach when learning to teach SWD as it allows students to apply theoretical knowledge in an authentic field based experience (Apache \& Rizzo, 2005; Coates, 2012; Di Nardo et al., 2014; Gursel, 2007; Pedersen et al., 2014; Perlman \& Piletic, 2012; Schoffstall et al., 2007).

Among the studies evaluating the impact of coursework, it was found a hands-on approach conducted through APE courses created opportunities for pre-service PE teachers to develop their pedagogy towards working with SWD (Di Nardo et al., 2014; Everhart, 2009; Gursel, 2007; Perlman \& Piletic, 2012; Schoffstall et al., 2007). Not surprisingly, the overall findings from these studies found that more education was beneficial for developing inclusive pedagogy (Gursel, 2007) and made pre-service teachers feel more prepared when instructing SWD (Schoffstall et al., 2007). Even so, Di Nardo et al. (2014) expresses a need to explore the differences among those who have or have not completed a course related to teaching SWD and how this affects their practice. In turn, this may provide further evidence for PETE programs to consider their curriculum and how it provides hands-on opportunities to enact inclusive pedagogy for SWD in PE (Pedersen et al., 2014). 


\section{Conclusion}

This review examined literature from 2005-2015 encompassing studies about pre-service Physical Education (PE) teachers and their attitudes towards working with students with disabilities (SWD). Studies within this review were examined using a thematic approach and highlighted key themes and their implications. Key themes identified for discussion included; (a) measurements to examine attitudes of pre-service PE teachers, (b) exploring pre-service PE teacher's self-efficacy; (c) the effects of pre-service PE teachers' practicum experiences; and (d) investigating the hands-on opportunities in Physical Education Teacher Education (PETE) programs. Themes discussed in this review contribute to enabling better learning outcomes for pre-service PE teachers in developing inclusive pedagogy when working with SWD in PE.

From the review, the authors have identified a need to review current PETE programs to explore the curriculum and if and how inclusive pedagogy is incorporated into student learning outcomes. It is important to examine the opportunities presented in PETE programs to determine if they are adequate in preparing pre-service PE teachers to provide opportunities in PE for SWD (Perlman \& Piletic, 2012). Furthermore, Pedersen et al. (2014) argue that a comprehensive PETE program is warranted in Australian universities. Pedersen et al. (2014) believe that this should include an APE topic where it will have a positive impact on pre-service PE students' pedagogy. It was evident from the records identified in database searches that Australia has limited research in the area of pre-service PE teachers and their attitudes towards working with SWD. To the authors' knowledge, Martin and Kudlacek's (2010) study from a New South Wales University, and the examination by Pedersen et al. (2014) across two universities in Tasmania and Victoria are the only studies in Australia concerning pre-service PE teachers and their attitudes towards working with SWD. Thus, this review supports a further exploration of Australian pre-service PE teachers and their self-efficacy to design and enact inclusive pedagogy. Subsequently, this study needs to explore inclusive pedagogy in physical education on a state-wide basis and how it can become embedded throughout an entire PETE program. 


\section{References}

Ajzen, I. (1991). The theory of planned behaviour. Organizational Behaviour and Human Decision Processes, 50, 179-211.

Ajzen, I. (2002). Constructing a TpB questionnaire: conceptual and methodological considerations. Retrieved: $h$ ttp://chuang.epage.au.edu.tw/ezfiles/168/1168/attach/20/pta_41176_7688352_57138. $p d f$

Apache, R. R. G., \& Rizzo, T. (2005). Evaluating effectiveness of an infusion learning model on attitudes of physical education majors. Perceptual and Motor Skills, 101(1), 177-186.

Armstrong, F., Armstrong, D. \& Barton, L (Ed.) (2009). Inclusive education: policy, context and comparative perspectives. David Fulton Publishers: London.

Australian Curriculum Assessment and Reporting Authority (ACARA). (2015). Health and Physical Education. Retrieved from: http://www.australiancurriculum.edu.au/ health-and-physical-education/key-ideas

Australian Government. (2005). Disability Standards for Education 2005. Attorney- General's Department, Department of Education, Science and Training.

Australian Institute for Teaching and School Leadership (AITSL) (2011). Australian Professional Standards for Teachers. Retrieved from $h t t p: / / w w w . a i t s l . e d u . a u /$ australian-professional-standards-for-teachers/standards/list

Australian Institute of Health and Welfare (AlHW) (2008). Disability in Australia: trends in prevalence, education, employment and community living. Cat. no. AUS 103. Canberra: AlHW. Retrieved from: http://www.aihw.gov.au/WorkArea/DownloadAsset.aspx?id=6442452829

Bailey, R. (2005). Evaluating the relationship between physical education, sport and social inclusion. Educational Review, 57, 71-90. doi:10.1080/0013191042000274196

Ballard, K (1997). Researching disability and inclusive education: participation, construction and interpretation. International Journal of Inclusive Education, 1(3), 243-256.

Bandura, A. (1997) Self-efficacy: the exercise of control. New York: Freeman.

Block, M. E. \& Obrusnikova, I. (2007). Inclusion in physical education: A review of the literature from 1995-2005. Adapted Physical Activity Quarterly, 24(2), 103-124. doi:10.1123/apaq.24.2.103

Block, M. E., Hutzler, Y., Barak, S., \& Klavina, A. (2013). Creation and Validation of the Self-Efficacy Instrument for Physical Education Teacher Education Majors Toward Inclusion. Adapted Physical Activity Quarterly, 30(2), 184-205.

Coates, J. K. (2012). Teaching Inclusively: Are Secondary Physical Education Student Teachers Sufficiently Prepared to Teach in Inclusive Environments? Physical Education and Sport Pedagogy, 17(4), 349-365.

Corbett, J. (2001). Teaching approaches which support inclusive education: A connective pedagogy. British Journal of Special Education, 28(2), 55-59.

Di Nardo, M., Kudláček, M., Tafuri, D., \& Sklenaříková, J. (2014). Attitudes of preservice physical educators toward individuals with disabilities at university Parthenope of Napoli. Acta Gymnica, 44(4), 211-221. doi:10.5507/ag.2014.022

Disability and Discrimination Act 1992. Retrieved from: https://www.legis/ation.gov.au/Details/ C2016C00763

Duchane, K. A., Leung, R. W., \& Coulter-Kern, R. (2008). Preservice physical educator attitude toward teaching students with disabilities. Clinical Kinesiology, 62(3), 16-20. 
Everhart, B. (2009). Anxiety of Preservice Teachers Teaching Students with Disabilities: A Preliminary Investigation. Education, 129(4), 704-713.

Fethi, A. (2015). Examination of physical education teacher candidates' attitudes towards individuals with physical disability by visual information. Anthropologist, 21(1-2), 197-201.

Fishbein, M. A. (1967). Readings in attitude theory and measurement. New York, NY: Wiley

Government of South Australia (2010) Physical Education and Physical Activity: Opportunities for students with a disability. Retrieved from http://www.macswd.sa.gov.aulfiles/links/Physical_ Education_Report.pdf

Gursel, F. (2007). Attitudes of physical education majors in Turkey towards disability are changed by adaptive physical education training. Perceptual and Motor Skills, 104(1), 166-170.

Hodge, S. R. \& Elliott, G. (2013). Physical Education Majors' Judgments about Inclusion and Teaching Students with Disabilities. Journal of Education and Training Studies, 1(1), 151-157.

Hodge, S. R., Murata, N. M., \& Kozub, F. (2002). Physical educators' judgments about inclusion: A new instrument for pre-service teachers. Adapted Physical Activity Quarterly, 19, 435-452.

Hodge, S. R., Sato, T., Mukoyama, T., \& Kozub, F. M. (2013). Development of the Physical Educators' Judgments about Inclusion Instrument for Japanese Physical Education Majors and an Analysis of their Judgments. International Journal of Disability Development and Education, 60(4), 332-346. doi:10.1080/1034912x.2013.846468

Hutzler, Y., Zach, S., \& Gafni, O. (2005). Physical education students' attitudes and self-efficacy towards the participation of children with special needs in regular classes. European Journal of Special Needs Education, 20(3), 309-327. doi:10.1080/08856250500156038

Kudláček, M., Válková, H., Sherrill, C., Myers, B., \& French, R. (2002). An inclusion instrument based on planned behaviour theory for prospective physical educators. Adapted Physical Activity Quarterly, 19, 280-299.

Lieberman, L. J. \& Wilson, S. (2005). Effects of a Sports Camp Practicum on Attitudes toward Children with Visual Impairments and Deafblindness. RE: view: Rehabilitation Education for Blindness and Visual Impairment, 36(4), 141.

Mangope, B., Mannathoko, M. C., \& Kuyini, A. B. (2013). Pre-Service Physical Education Teachers and Inclusive Education: Attitudes, Concerns and Perceived Skill Needs. International Journal of Special Education 28(3), 82-92.

Martin, K. \& Kudlacek, M. (2010). Attitudes of pre-service teachers in an Australian university towards inclusion of students with physical disabilities in general physical education programs. European Journal of Adapted Physical Activity, 3, 30-48.

Mousouli, M., Kokaridas, D., Angelopoulou-Sakadami, N. \& Aristotelous, M. (2009) Knowledge and Attitudes towards Children with Special Needs by Physical Education Students. International Journal of Special Education, 24(3), 85-89.

Obrusníková, I., Válková, H., \& Block, M. E. (2003). Impact of inclusion in general physical education on students without disabilities. Adapted Physical Activity Quarterly, 20, 230 -245.

Oh, H.-K., Rizzo, T. L., So, H., Chung, D.-H., Park, S.-J., \& Lei, Q. (2010). Preservice Physical Education Teachers' Attributes Related to Teaching a Student Labeled ADHD. Teaching and Teacher Education: An International Journal of Research and Studies, 26(4), 885-890.

Oliver, M. (1983). Social Work with Disabled People. Basingstoke: Macmillan Education UK

Ouellette-Kuntz, H. (2005). Understanding health disparities and inequities faced by individuals with intellectual disabilities. Journal of Applied Research in Intellectual Disabilities, 18(2), 113-121. doi:10.1111/j.1468-3148.2005.00240.x 
Pedersen, S. J., Cooley, P. D., \& Hernandez, K. (2014). Are Australian Pre-Service Physical Education Teachers Prepared to Teach Inclusive Physical Education? Australian Journal of Teacher Education, 39(8), 11.

Perlman, D. \& C. Piletic (2012). The influence of an adapted physical education course on preservice teacher instruction: Using a self-determination lens. Australian Journal of Teacher Education 37(1), $1-18$.

Qi, J. \& Ha, A. S. (2012) Inclusion in Physical Education: A review of literature. International Journal of Disability, Development and Education. 59(3), 257-281. doi:10.1080/1034912X.2012.697737

Rizzo, T. L. (1993) Physical Educator's Attitude Toward Teaching Individuals with Disabilities-III. (Unpublished survey) (Available from the author, Department of Kinesiology, California State University, San Bernardino, CA 92407-2397)

Rust, R., \& Sinelnikov, O. (2010). Practicum in a Self-Contained Environment: Pre-Service Teacher Perceptions of Teaching Students with Disabilities. Physical Educator, 67(1), 33-45.

Schoffstall, J., \& Ackerman, B. (2007). Attitudes of Pre-Service Physical Educators at a Faith-Based University toward Individuals with Disabilities. Journal of Beliefs \& Values, 28(2), 183-193.

Shechtman, Z. (1991) Changing attitudes of teachers in regular education toward integrating the exceptional in regular settings: empirical findings and an intervention plan, Dapim, 13, 54-59

Tindall, D., MacDonald, W., Carroll, E., \& Moody, B. (2015). Pre-Service Teachers' Attitudes towards Children with Disabilities: An Irish Perspective. European Physical Education Review, 21(2), 206-221

United Nations (2006) Convention of the Right of Persons with Disabilities: Participation in cultural life, recreation, leisure and sport. Article 30, 5 (d). Retrieved from: http://www.un.org/esa/socdev/ enable/rights/convtexte.htm\#convtext

Vickerman, P. \& Coates, J.K. (2009) Trainee and recently qualified physical education teachers' perspectives on including children with special educational needs. Physical Education and Sport Pedagogy, 14(2), 137-153. doi: 10.1080/17408980802400502

Wallhead, T. \& O'sullivan, M. (2005) Sport Education: physical education for the new millennium? Physical Education and Sport Pedagogy, 10(2), 181-210. doi: 10.1080/17408980500105098

Wilczenski, L. F. (1995). Development of a scale to measure attitudes toward inclusive education. Educational and Psychological Measurement, 55(2), 291-299.

Yuker, H. E., Block, J, R., \& Young, J.H. (1970) The Measurement of Attitudes Towards Disabled Person Scale. Albertson, NY: Ina Mend Institution 